American Journal of Environmental Sciences 3 (4): 205-218, 2007

ISSN $1553-345 \mathrm{X}$

(C) 2007 Science Publications

\title{
Removal of Dye from Textile Wastewater Using Plant Oils Under Different pH and Temperature Conditions
}

\author{
A. S. Mahmoud, A.E. Ghaly and M.S. Brooks \\ Department of Process Engineering and Applied Science, Dalhousie University \\ Halifax, Nova Scotia, Canada B3J2X4
}

\begin{abstract}
The effectiveness of five plant oils (cottonseed, olive, canola sunflower and used cooking oil) for the removal of dye from textile wastewater was evaluated. The study revealed that the dye removal efficiency increased as the temperature was increased. Under low $\mathrm{pH}$, both the oil and dye split into two components each. Neither one of the oil components joined with either one of the dye components. However, the observed reduction in the absorbance under acidic conditions can be attributed to the dye components losing some of their original color or producing different colors that were not effectively measured at $475 \mathrm{~nm}$. When the dye solution was shaken with the oil under alkaline conditions, it formed a colloidal solution containing the oil plus the dye, resulting in a significant dye removal from solution. The results also showed that the optimum conditions for the dye removal for various oils were at a $\mathrm{pH}$ of 13 and a temperature of $55{ }^{\circ} \mathrm{C}$, except for canola oil that produced the highest dye removal efficiency at $\mathrm{pH}$ of 7 . The used cooking oil achieved the highest dye removal efficiency $(95.45 \%)$ followed by olive oil $(87.00 \%)$. The other oils (cottonseed, canola and sunflower achieved dye removal efficiencies below $58 \%$ and are, therefore, not recommended for dye removal.
\end{abstract}

Key words: Textile wastewater, remazol brilliant blue, reactive dye, plant oils, used oil, pH, temperature

\section{INTRODUCTION}

Reactive dyes are the principal dyes used in the cotton industry which makes up 50\% of the world's fiber consumption ${ }^{[1]}$. They are commonly used in the textile industry because of their bright colours, excellent colourfastness and ease of application ${ }^{[2,3]}$. A large number of reactive dyes are azo compounds that are linked by an azo group ${ }^{[4]}$. Many reactive dyes are toxic to some organisms and may cause direct destruction of aquatic life due to the presence of aromatic and metal chlorides ${ }^{[5]}$. It has been reported that some azo dyes are able to produce carcinogenic aromatic amines in the process of reductive degradation ${ }^{[6,7]}$. Their high solubility, synthetic origin and complex aromatic molecular structure make their removal a very difficult task ${ }^{[8,9]}$.

Methods for treating textile dye wastewaters consist of various chemical, physical and biological processes. These include: adsorption ${ }^{[10]}$, nanofiltration ${ }^{[11,12]}$, colloidal gas aphrons ${ }^{[13]}$, ultrasonic decomposition $^{[14]}$, electro coagulation ${ }^{[15]}$, coagulation and precipitation ${ }^{[16]}$, advanced chemical oxidation ${ }^{[17]}$, electrochemical oxidation ${ }^{[18-19]}$, photooxidation ${ }^{[18]}$, predispersed solvent extraction ${ }^{[20]}$, ozonation ${ }^{[21-24]}$, supported liquid membrane ${ }^{[2,25,26]}$, liquid- liquid extraction $^{[25,27]}$ and aerobic and anaerobic biological processes $^{[28,29]}$. The advantages and disadvantages of some methods of dye removal from wastewater are given in Table 1.

The liquid membrane technique known as "Supported Liquid Membrane" (SLM) has the advantage of achieving selective removal and concentration in single stage, thus having great potential for reducing cost significantly ${ }^{[2]}$. SLM system has several advantages including: (a) low capital investment and operating cost, (b) low energy consumption, (c) minimal loss of extractant, (d) low liquid membrane requirement and thus less amount of expensive extractants which offer good selectivity and (e) simple to operate and easy to scale up. There have been a number of studies dealing with organic compound transport through SLM in synthetic solutions ${ }^{[27]}$. However, no work has been carried out on the use of liquid membrane technology to recover textile dyes.

Corresponding Author: Abdel Ghaly, Department of Process Engineering and Applied Science, Dalhousie University, Halifax, Nova Scotia, Canada, B3J 2X4; Tel: (902) 494-6014; Fax: (902) 420-7639 


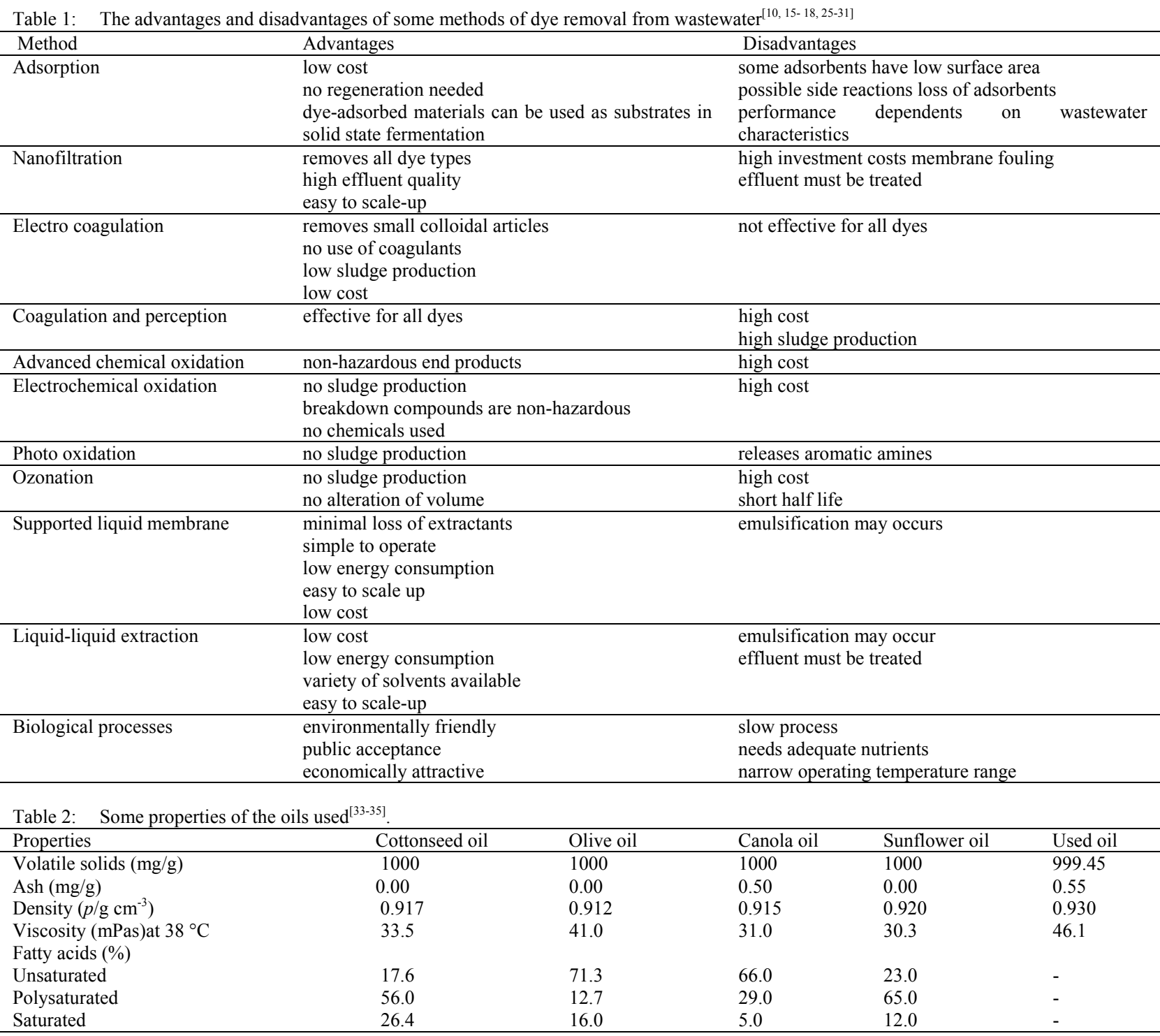

The aim of this study was to investigate the potential of using renewal, non-toxic, natural plant oils as a liquid membrane for the removal of the dye remazal brilliant blue from the textile wastewater. The specific objectives were: (a) to evaluate the effectiveness of five oils (cottonseed oil, olive oil, canola oil, sunflower oil and used cooking oil) for removal of the textile dye remazol brilliant blue and (b) to investigate the effects of $\mathrm{pH}$ and temperature on the dye removal efficiency.

\section{MATERIALS AND METHODS}

Oils: Four types of commercially available plant oils (cottonseed oil, olive oil, canola oil and sunflower oil) were purchased from a local supermarket in Halifax. Used cooking oil was obtained from a local restaurant in Halifax. Some properties of these oils are shown in Table 2 . The viscosity of the fresh oil was given by the manufactories, while the viscosity of cooked oil was measured using Bohlin VOR Rheometer (Bohlin Instroments, Cranbooy N.J., USA). 


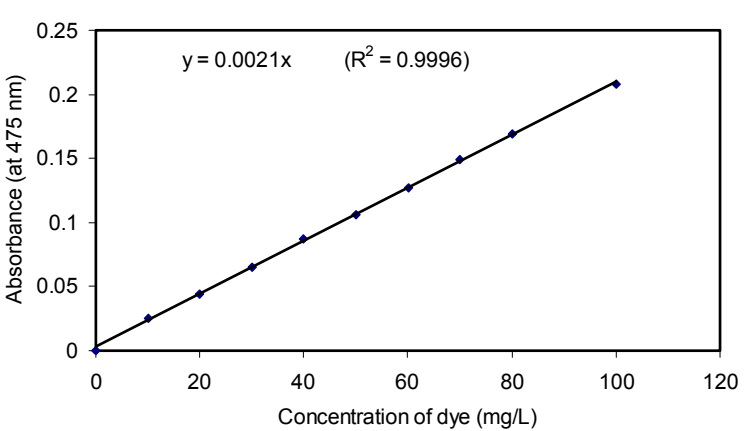

Fig. 1: $\quad$ Standard curve $\left(\mathrm{pH}=7\right.$, temperature $\left.25^{\circ} \mathrm{C}\right)$

Reagents: The chemicals used in this study included sodium hydroxide $(\mathrm{NaOH})$, sulphuric acid $\left(\mathrm{H}_{2} \mathrm{SO}_{4}\right)$ and remazol Brilliant blue dye (1-amino-4-[4-(1-sulfonylethyl-2- sulfoxy)]-2-(9, 10-anthraquinone)-sulfonic acid; disodium salt,). The $98.6 \% \mathrm{NaOH}$ and $98 \%$ $\mathrm{H}_{2} \mathrm{SO}_{4}$ were obtained from Fisher Scientific $(\mathrm{Ca} \# \mathrm{~S}$ 318-3 and Ca \#A 300 212, Fisher Scientific, Montreal, Quebec, Canada). The remazol brilliant blue, dye content $\sim 50 \%$ was obtained from Sigma (R8001, Ca \# 22-324-7, Sigma, Oakville, Ontario, Canada).

Standard curve: To determine the concentration of the remazol brilliant blue dye using colorimetric techniques, a standard curve was developed from the standard solution of remazol brilliant blue dye according to the procedure described by Mahmoud et $a l .{ }^{[36]}$. The standard solution was prepared by dissolving $0.1 \mathrm{~g}$ of the dye in $1000 \mathrm{~mL}$ of distilled deionized water at ambient conditions ( $\mathrm{pH}$ of 7 and a temperature of 25 ${ }^{\circ} \mathrm{C}$ ). Then, a set of 9 solutions with remazol blue dye concentrations of 10, 20,30, 40, 50, 60, 70, 80 and 100 $\mathrm{mg} / \mathrm{L}$ was prepared. Finally, the absorbance of the prepared solutions was measured (in triplicate) using a spectrophotometer (Spectronic 601, Fisher scientific, Montreal, Quebec, Canada). The absorbance was then plotted against the known remazol blue dye concentrations $(\mathrm{mg} / \mathrm{L})$ as shown in Fig. 1. A blank sample was used to zero the spectrophotometer.

Experimental design: The effects of oil type, $\mathrm{pH}$ and temperature on the removal of remazol brilliant blue from textile wastewater were investigated. Five types of plant oil (cottonseed oil, olive oil, canola oil, sunflower oil and used cooking oil), five levels of $\mathrm{pH}(1,4,7,10$ and 13) and five temperatures $(15,25,35,45$ and $55^{\circ} \mathrm{C}$ ) were investigated. The experiments were designed as $5^{3}$ factorials with 3 replicates. This resulted in 375 treatments.
Experimental procedure: A volume of $500 \mathrm{~mL}$ of each of the five solutions ( $\mathrm{pH}=1,4,7,10$ or 13$)$ was prepared according to the procedure described by Mahmoud et al. ${ }^{[36]}$. A water bath (280, Precision Scientific, Winchester, VA, USA) was used to maintain a constant temperature of these solutions. Three replicates were prepared for each $\mathrm{pH}$ solution by placing $100 \mathrm{~mL}$ of the solution in a $200 \mathrm{~mL}$ Erlenmeyer flask. The water bath temperature was maintained at $15^{\circ} \mathrm{C}$. When the temperature reached a constant value, the flasks were placed in the water bath until the temperature of the solutions reached the desired temperature (one hour was needed). An amount of 0.03 $\mathrm{g}$ of the dye was added to each flask. The flasks were kept in the water bath for additional 15 minutes. The absorbance of the dye solution was measured using a spectrophotometer (Spectronic 601, Fisher scientific, Montreal, Quebec, Canada) at $475 \mathrm{~nm}$. Then, $6 \mathrm{~mL}$ of the dye solution was taken from each flask and placed into fiften $20 \mathrm{~mL}$ test tubes ( 3 replicates for each $\mathrm{pH}$ ). Then, $6 \mathrm{~mL}$ of the oil was added to each test tube and mixed well with the dye solution for 2 minutes using a vortexer (Model number: M16715, Barnstead, Dubuque, Iowa 52001 USA). The test tubes were then placed in the water bath until the temperature of the solution reached the desired temperature and complete separation between the oil and the solution occurred. The absorbance of the dye solution in bottom layer of each test tube was measured using the spectrophotometer at $475 \mathrm{~nm}$. The same procedure was used for all the oil types studied and the entire process was repeated with the other temperatures investigated $\left(25,35,45\right.$ and $\left.55^{\circ} \mathrm{C}\right)$.

\section{RESULTS AND DISCUSSION}

The effects of temperature and $\mathrm{pH}$ on the dye removal efficiency of different oils are shown in Table 3 and presented in Fig. 2-6. Analysis of variance was performed on the dye removal efficiency data using the SAS system ( $5^{\text {th }}$ ed, SAS, lastitrote inc, cery, North Carolina) as shown in Table 4. Duncan's multiple range test was also performed on the data in order to test the differences among the levels of each factor as shown in Table 5. The results showed that the type of oil, $\mathrm{pH}$ and temperature had significant effects on removal efficiency of the dye $(\mathrm{P}=0.0001)$. There were also significant interactions between the parameters $(\mathrm{P}=0.0001)$. The effect of $\mathrm{pH}$ was more pronounced than the type of oil and temperature and the five levels of $\mathrm{pH}$ were significantly different from one another at the $95 \%$ confidence level. 
Am. J. Environ. Sci., 3 (4): 205-218, 2007

Table 3: Effect of temperature and $\mathrm{pH}$ on dye reduction using different oils

\begin{tabular}{|c|c|c|c|c|c|c|}
\hline \multirow{2}{*}{$\begin{array}{c}\text { Oil } \\
\text { Type }\end{array}$} & \multirow[b]{2}{*}{ Temperature ${ }^{\circ} \mathrm{C}$} & \multicolumn{5}{|c|}{ Reduction in dye concentration (\%) } \\
\hline & & $\mathrm{pH} 1$ & $\mathrm{pH} 4$ & pH 7 & $\mathrm{pH} 10$ & pH 13 \\
\hline \multirow{5}{*}{ Cottonseed } & 15 & 23.39 & 24.63 & 25.76 & 30.31 & 45.85 \\
\hline & 25 & 28.24 & 28.90 & 33.95 & 37.92 & 48.90 \\
\hline & 35 & 28.55 & 29.90 & 36.68 & 45.07 & 54.63 \\
\hline & 45 & 30.70 & 35.40 & 39.69 & 49.70 & 56.32 \\
\hline & 55 & 33.50 & 40.86 & 42.48 & 50.07 & 58.06 \\
\hline \multirow[t]{5}{*}{ Olive } & 15 & 22.60 & 24.81 & 26.42 & 28.24 & 49.43 \\
\hline & 25 & 28.33 & 31.06 & 31.40 & 32.94 & 79.34 \\
\hline & 35 & 30.08 & 34.18 & 37.30 & 41.26 & 82.71 \\
\hline & 45 & 35.00 & 40.39 & 50.39 & 52.36 & 85.17 \\
\hline & 55 & 42.52 & 44.54 & 53.75 & 59.63 & 87.00 \\
\hline \multirow[t]{5}{*}{ Canola } & 15 & 24.83 & 29.39 & 32.33 & 38.49 & 39.74 \\
\hline & 25 & 28.76 & 35.27 & 38.94 & 40.55 & 45.09 \\
\hline & 35 & 30.32 & 39.01 & 41.98 & 46.22 & 47.93 \\
\hline & 45 & 31.78 & 39.89 & 45.41 & 48.18 & 50.90 \\
\hline & 55 & 34.34 & 39.90 & 50.12 & 52.03 & 53.06 \\
\hline \multirow[t]{5}{*}{ Sunflower } & 15 & 30.15 & 32.92 & 38.62 & 40.60 & 42.20 \\
\hline & 25 & 30.82 & 32.95 & 38.95 & 43.26 & 44.29 \\
\hline & 35 & 32.64 & 35.00 & 40.82 & 44.47 & 46.04 \\
\hline & 45 & 33.28 & 36.10 & 43.90 & 50.54 & 52.40 \\
\hline & 55 & 38.00 & 39.45 & 45.73 & 51.91 & 58.08 \\
\hline \multirow[t]{5}{*}{ Used cooking oil } & 15 & 25.30 & 27.18 & 29.84 & 35.00 & 72.97 \\
\hline & 25 & 28.81 & 29.67 & 31.19 & 42.14 & 87.60 \\
\hline & 35 & 37.34 & 37.93 & 39.78 & 52.96 & 89.71 \\
\hline & 45 & 38.95 & 41.17 & 50.59 & 54.27 & 95.04 \\
\hline & 55 & 41.36 & 48.86 & 58.33 & 64.69 & 95.45 \\
\hline
\end{tabular}

Effect of oil type on dye removal efficiency: Removal of hazardous dyes from textile effluent is one of the important factors affecting the economic and environmental sustainability of the industry ${ }^{[37]}$.

Vegetable oils are non-hazardous, cheap chemicals that could be used a novel and environmentally-friendly liquid medium (LM) in a supported liquid membrane (SLM) dye removal system. These vegetable oils are naturally-occurring, easily-available and renewable sources ${ }^{[26]}$. The results shown in Table 3 indicated that the used oil was the best suitable liquid membrane for removal of dye $(95.45 \%)$ followed by the olive oil $(87.00 \%)$. The other oils achieved little over $50 \%$ removal efficiency $(58.08,58.06$ and $53.06 \%$ for cottonseed oil, sunflower oil and canola oil respectively). This higher removal efficiency of the used oil and olive oil may be due to their high viscosity (46.1 and $41.0 \mathrm{mPas}$ for used and olive oils, respectively) as shown in Table 2 . The other oils had a viscosity in the range of $30.3-33.5 \mathrm{mPas}$.

Muthuraman and Palanivelu ${ }^{[38]}$ reported that palm oil, sunflower and coconut oils are very suitable liquid membranes for transport of dye from aqueous feed solution (wastewater) to strip solution $\left(\mathrm{H}_{2} \mathrm{SO}_{4}\right)$. The authors found no transport of dye when using castor oil as liquid medium due to its high viscosity which prevented the mass transfer. Using olive, gingerly, groundnut and mustard oils as a liquid membrane, there

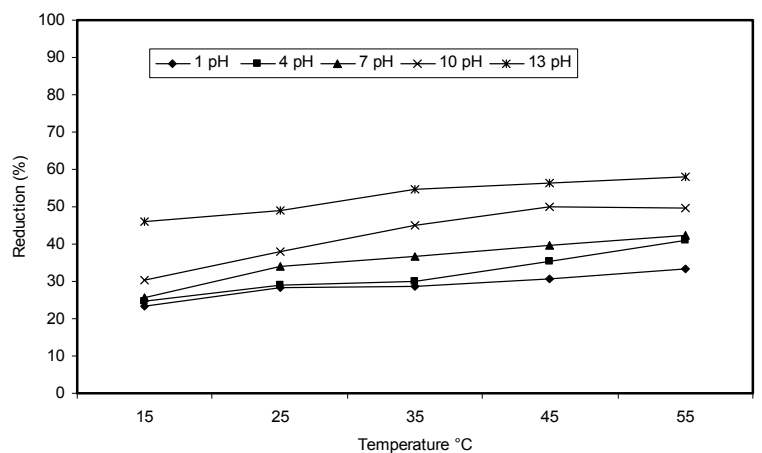

(a) Temperature

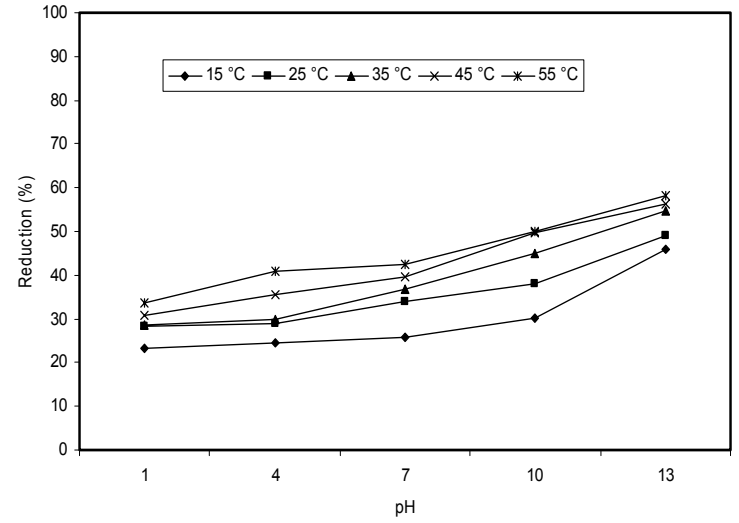

(b) $\mathrm{pH}$

Fig. 2: Effect of temperature and $\mathrm{pH}$ on the dye removal using cottonseed oil 


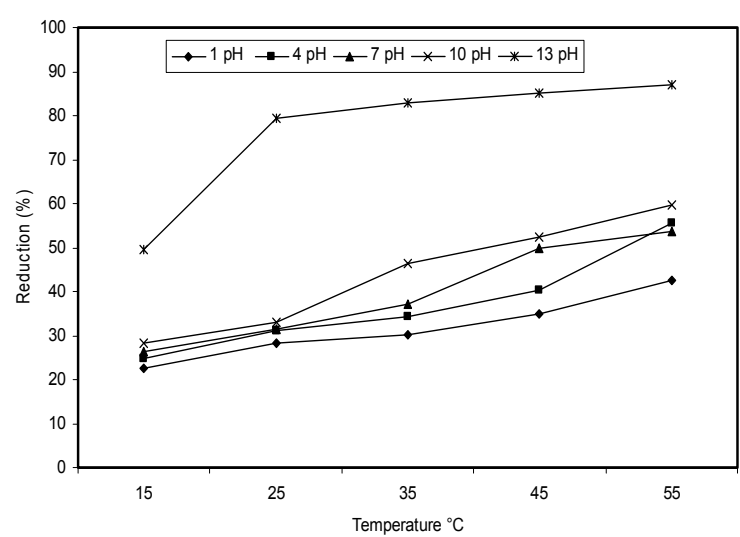

(a) Temperature

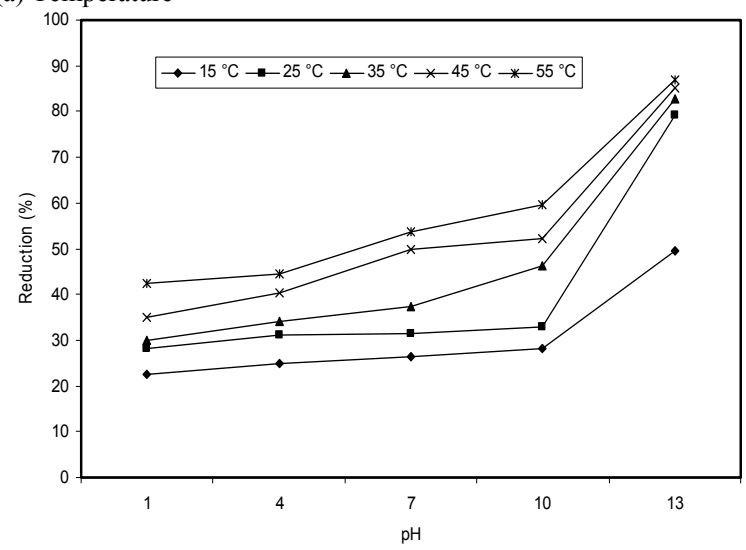

(b) $\mathrm{pH}$

Fig. 3: Effect of temperature and $\mathrm{pH}$ on the dye removal using olive oil

was a dye accumulation on the surface of the membrane during the transportation, so these LMs are skipped out for further studies. There was also no transport of dye without oil impregnation of the membrane suggesting the need for the hydrophobic oil for the transport of dye.

Venkateswaran and Palanivelu ${ }^{[26]}$ suggested that vegetable oils have the ability to dissolve phenolic substances because of their hydrophobic characters. The authors tested nine types of vegetable oils (castor, refined coconut, unrefined coconut, gingerly, groundnut, mustard, olive, palm and sunflower) for their efficiency in transporting phenol through supported liquid membranes (SLM). Among the tested oils, palm oil had the highest permeability $\left(8.5 \times 10^{-6} \mathrm{~m} / \mathrm{s}\right)$ whereas the castor oil had the lowest permeability $\left(2.4 \times 10^{-6} \mathrm{~m} / \mathrm{s}\right)$. They concluded that palm oil had higher distribution coefficient than other oils used in the study.

Effect of the temperature on the dye removal efficiency: The results obtained from this study showed
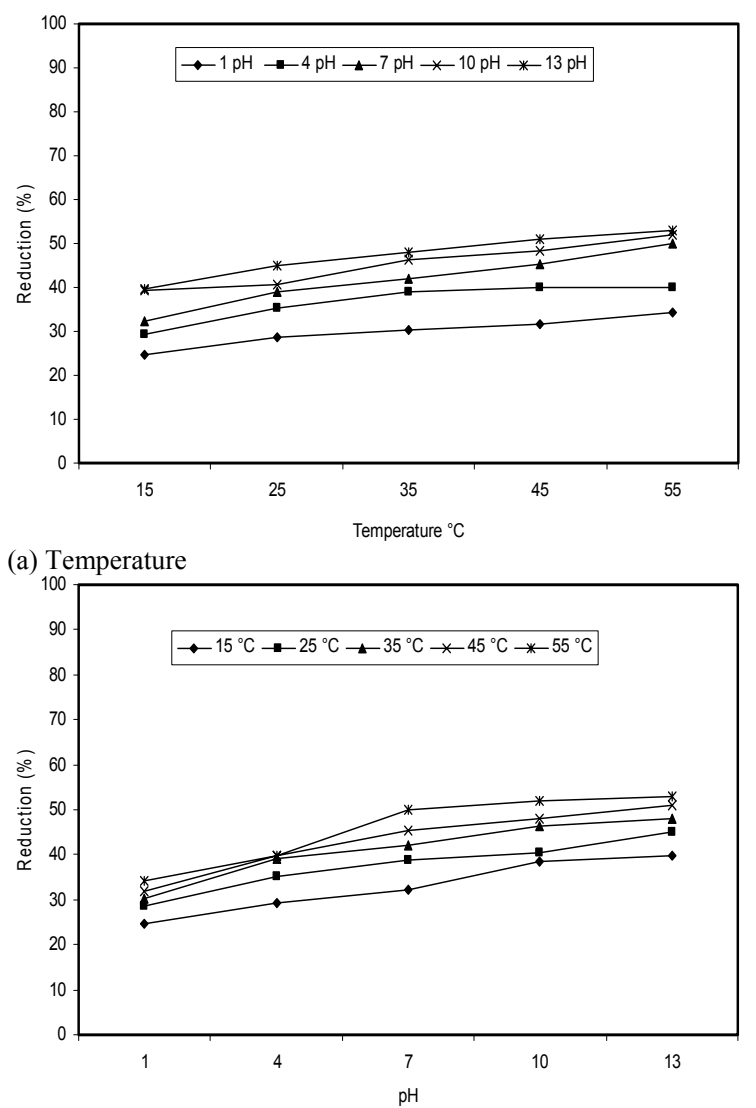

(b) $\mathrm{pH}$

Fig. 4: Effect of temperature and $\mathrm{pH}$ on the dye removal using canola oil

that the dye removal efficiency increased as the temperature increased for all oils and at all $\mathrm{pH}$ levels. Generally, the effect of temperature on rates of chemical reaction is important. Ordinarily, raising the temperature by $10^{\circ} \mathrm{C}$ approximately doubles the rate of most but not all reactions. This is because the molecules are more likely to become sufficiently energy-rich to reach the required activation levels needed to undergo reactions by the increase in temperature ${ }^{[25]}$.

The temperature of the medium has been shown to affect the dye removal process. Mittal et al. ${ }^{[37]}$ used deoiled soya as a waste for removal and recovery of malachite green from wastewater and found increases in the removal efficiency with increases in temperature (from 30 to $50^{\circ} \mathrm{C}$ ).

Al-Qodah et $a l .{ }^{[39]}$ reported on the effect of temperature on the adsorption process. Increasing the temperature is known to increase the rate of diffusion of the adsorbate molecules across the external boundary layer and in the internal pores of the adsorbent particle, owing to the decrease in the $\mathrm{v}$ iscosity of the dye 


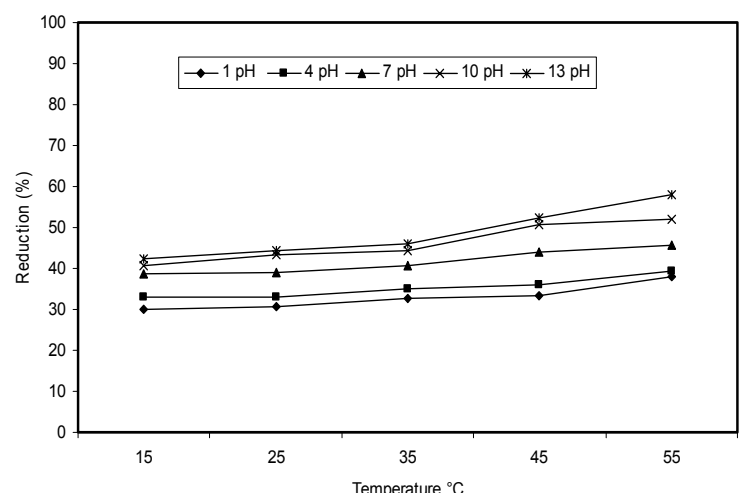

(a) Temperature

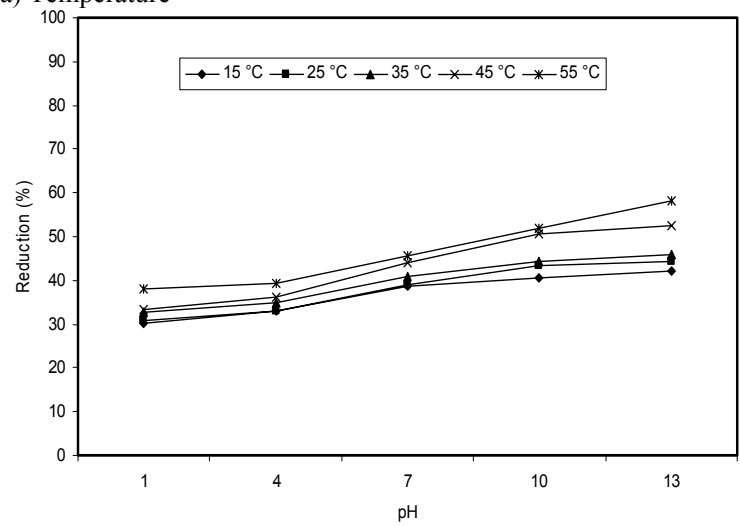

(b) $\mathrm{pH}$

Fig. 5: Effect of temperature and $\mathrm{pH}$ on the dye removal using sunflower oil

solution. Changing the temperature will change the equilibrium capacity of the adsorbent for a particular adsorbate. The authors reported an increase in the mass transfer coefficient (from $2 \times 10^{-6}$ to $4.2 \times 10^{-6} \mathrm{~m} / \mathrm{s}$ ) and in the diffusion coefficient (from $0.9 \times 10^{-10}$ to $1.2 \times 10^{-10}$ $\mathrm{cm}^{2} / \mathrm{s}$ ) as the temperature increased from 20 to $45^{\circ} \mathrm{C}$.

Tsatsaroni ${ }^{[40]}$ studied the degradation of azo disperse dye at high temperature $125^{\circ} \mathrm{C}$ using dye dispersions of $0.004,0.02$ and $0.1 \%$ dye concentration in buffer solutions of $\mathrm{pH} \mathrm{4,7}$ and 9. The result showed that the color change from yellow in nonpolar solvents (toluene, chlorobenzene) to greenish blue in polar solvents (acetone, ethanol), due to dealkylation of the amino group of the coupler, followed by oxidation of the amino group and nucleophilic substitution of the resultant moiety by a hydroxy group in the strongly alkaline medium due to the high temperature.

Effect of $\mathrm{pH}$ on the dye removal efficiency: The structure of remazol brilliant blue dye and a general structure of a plant oil are shown in Fig. 7. The molecular formula of remazol brilliant blue $\mathrm{R}$ dye [1amino-4-[ 4-(1-sulfonyl-ethyl-2- sulfoxy)]-2-(9,10-

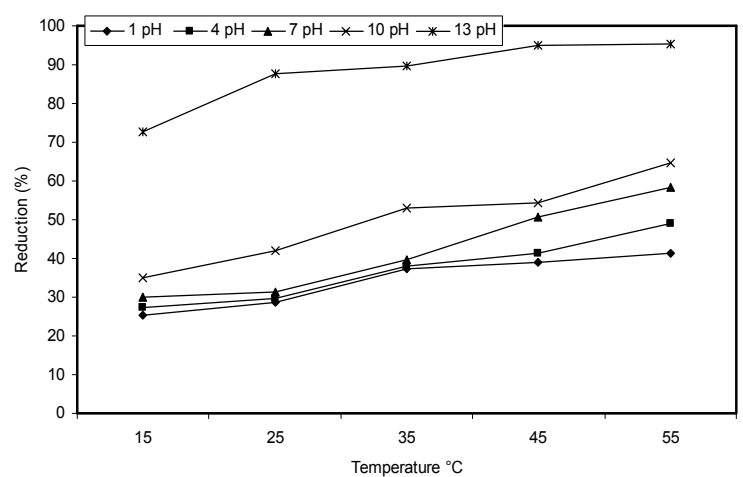

(a) Temperature

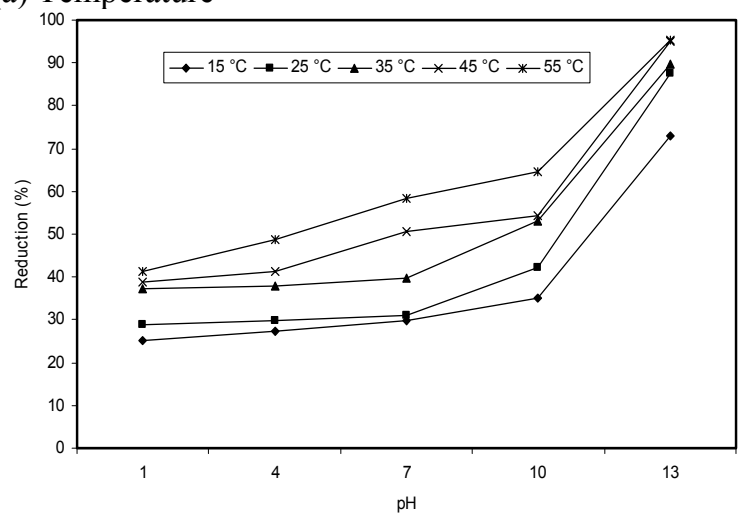

(b) $\mathrm{pH}$

Fig. 6: Effect of temperature and $\mathrm{pH}$ on the dye removal using used oil

anthraquinone)-sulfonic acid; disodium salt] is $\mathrm{C}_{22} \mathrm{H}_{16} \mathrm{~N}_{2} \mathrm{Na}_{2} \mathrm{O}_{11} \mathrm{~S}_{3}$. Remazol brilliant blue $\mathrm{R}$ is an aromatic compound containing anthraquinone and amino, sulfonyl, ethyl, sulfoxy groups and sulfonic acid disodium salt ${ }^{[41]}$. The plant oil is a complex mixture of chemically distinct components, with triglycerides consisting of various fatty acids (palmitic acid, lauric, caprylic, capric, eruic acids) as major constituents ${ }^{[42]}$.

Acidic condition: Under acidic conditions (low $\mathrm{pH}$ ), the hydrogen ion $\left(\mathrm{H}^{+}\right)$in the medium is attracted to the polar end of the triglycerides in plant oil structure making the outer part of each micelle positively charged. Then, this ionic compound reacts with $\mathrm{H}_{2} \mathrm{O}$ to produce a carbonium ion compound which then splits into a diglyceride plus one free fatty acid releasing a hydrogen ion $\left(\mathrm{H}^{+}\right)$back to the medium as shown in Fig. $8^{[43]}$.

The hydrogen ion $\left(\mathrm{H}^{+}\right)$in the medium can then react with the amino group $\left(\mathrm{NH}_{2}\right)$ at carbon $\# 1$ in the anthraquinone third ring of the remazol brilliant blue dye structure to from $\mathrm{NH}_{3}$. This results in the formation of the ionic form of the dye $\left[\mathrm{C}_{22} \mathrm{H}_{17} \mathrm{~N}_{2} \mathrm{Na}_{2} \mathrm{O}_{11} \mathrm{~S}_{3}\right]^{+}$ 
Am. J. Environ. Sci., 3 (4): 205-218, 2007

\begin{tabular}{|c|c|c|c|c|c|}
\hline Source & $\mathrm{DF}$ & SS & MS & F & $\mathrm{P}$ \\
\hline Total & 374 & 87621.80 & & & \\
\hline Model & 124 & 44226.85 & & & \\
\hline $\mathrm{O}$ & 4 & 7026.66 & 1756.67 & 315.81 & 0.0001 \\
\hline $\mathrm{P}$ & 4 & 44785.54 & 11196.38 & 2012.89 & 0.0001 \\
\hline $\mathrm{T}$ & 4 & 14444.43 & 3611.11 & 649.20 & 0.0001 \\
\hline $\mathrm{O} * \mathrm{P}$ & 16 & 14787.89 & 924.24 & 166.16 & 0.0001 \\
\hline $\mathrm{O} * \mathrm{~T}$ & 16 & 2380.49 & 148.78 & 26.75 & 0.0001 \\
\hline $\mathrm{P} * \mathrm{~T}$ & 16 & 971.68 & 60.73 & 10.92 & 0.0001 \\
\hline $\mathrm{O} * \mathrm{P} * \mathrm{~T}$ & 64 & 1834.52 & 28.66 & 5.15 & 0.0001 \\
\hline Error & 250 & 1390.59 & 5.56 & & \\
\hline $\mathrm{R}^{2}=98.41 \mathrm{CV}=35.64 \%$ & $\mathrm{O}=$ oil $\quad \mathrm{P}=\mathrm{pH}$ & $\mathrm{T}=$ temperature & & & \\
\hline $\begin{array}{l}\text { 1able 5: Differences an } \\
\text { Parameter }\end{array}$ & the levels o & No. of Observations & & Means & Duncan Grouping \\
\hline \multirow[t]{5}{*}{ Oil } & Used oil & 75 & & 50.24 & $\mathrm{~A}$ \\
\hline & Olive oil & 75 & & 45.42 & $\mathrm{AB}$ \\
\hline & Canola oil & 75 & & 40.39 & B \\
\hline & Sunflower oil & 75 & & 40.28 & $\mathrm{BC}$ \\
\hline & Cottonseed oil & 75 & & 38.40 & $\mathrm{C}$ \\
\hline \multirow[t]{5}{*}{ Temperature $\left({ }^{\circ} \mathrm{C}\right)$} & 55 & 75 & & 51.33 & $\bar{A}$ \\
\hline & 45 & 75 & & 45.60 & A \\
\hline & 35 & 75 & & 42.98 & B \\
\hline & 25 & 75 & & 39.17 & B \\
\hline & 15 & 75 & & 33.65 & $\mathrm{C}$ \\
\hline \multirow[t]{5}{*}{$\mathrm{pH}$} & 13 & 75 & & 62.84 & $\mathrm{~A}$ \\
\hline & 10 & 75 & & 44.98 & B \\
\hline & 7 & 75 & & 40.17 & $\mathrm{C}$ \\
\hline & 4 & 75 & & 35.15 & $\mathrm{D}$ \\
\hline & 1 & 75 & & 31.59 & E \\
\hline
\end{tabular}

Means with the same letter are not significantly different from each other at the $95 \%$ confidence level.

which has positive charge on the $\mathrm{NH}_{3}$ group. This new ionic compound is unstable and two hydrogen atoms from $\mathrm{NH}_{3}{ }^{+}$in remazol brillent blue dye are released in the form of hydrogen gas $\left(\mathrm{H}_{2}\right)$, resulting in the transfer of the positive charge to $\mathrm{NH}$ in carbon $\# 4^{[19]}$. This new ionic compound is also unstable so after and in presence of $\mathrm{H}_{2} \mathrm{O}$ it splits into two components: one neutral compound containing the anthraquinone rings which is considered to be the chromophore (a part or moiety of a molecule responsible for its color) in the dye structure and the other compound carrying a positive charge at $\mathrm{NH}_{3}$ which is located at carbon \# 1' in benzyl ring. This compound is an anilinium derivative [anilinium 3- (sulfonyl-ethyl-sulfoxy-sodium salt)] as shown in Fig. 9. Benelield et al. ${ }^{[4]]}$ reported that the chromophore type in Remazol brilliant blue R is anthraquinone.

Dye molecules are used to impart color to materials and by doing so, become an integral part of the fabric. An aromatic ring structure coupled with a side chain is usually required for resonance and thus to impart color. Resonance structures are responsible for color as they can cause displacement or appearance of absorption bands in the visible spectrum of light. Correlation of a chemical structure with color has been accomplished in<smiles>Nc1c(S(=O)(=O)O)cc(Nc2cccc(OS(=O)(=O)O[Na])c2)c2c1C(=O)c1ccccc1C2=O</smiles>

(a) The structure of remazol brilliant blue $\mathrm{R}$ dye ${ }^{[19]}$<smiles>[R]C(=O)OCCC(CC)(CC)OC([R])=O</smiles>

(b) The structure of plant oil (R,R'and R"are the type of fatty acid) ${ }^{[35]}$ Fig. 7: Chemical structures of remazol brilliant blue and plant oil

the synthesis of dye using a chromogen-chromophore with auxochrome. Chromogen is an aromatic structure containing benzene, naphthalene, or anthracene rings. A chromophore group is a color giver and is represented 
Step 1<smiles>[R]C(=O)OCCOC([R])=O</smiles><smiles>[R]C(=O)OCCOC([R1])=O</smiles>

Step 2<smiles>[R]C(=O)OC</smiles>

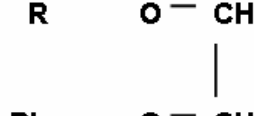

$\mathbf{R}^{\prime}$<smiles>[R1]C(=O)OCCOC(C)=O</smiles>

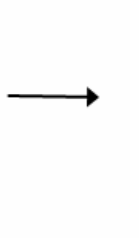<smiles>[R]C(=O)OCCC(=O)OC([R1])(O)O</smiles>

Step 3<smiles>[R]C(=O)OCCC[C@]([R])(O)C([R17])(O)OC([R])=O</smiles>

Fig. 8: Effect of low $\mathrm{pH}$ on the structure of plant oil ${ }^{[43]}$

by the following radicals, which form a basis for the chemical classification of dyes when coupled with the chromogen: azo $(-\mathrm{N}=\mathrm{N}-)$; carbonyl $(=\mathrm{C}=0)$; carbon $(=\mathrm{C}=\mathrm{C}=) ; \quad$ carbon-nitrogen $\quad(>\mathrm{C}=\mathrm{NH} \quad$ or $\quad-\mathrm{CH}=\mathrm{N}-)$ : nitroso $(-\mathrm{NO}$ or $\mathrm{N}-\mathrm{OH})$ : nitro $\left(-\mathrm{NO}_{2}\right.$ or $\left.=\mathrm{NO}-\mathrm{OH}\right)$ : and sulfur $(>\mathrm{C}=\mathrm{S}$ and other carbon-sulfur groups). The chromogen-chromophore structure is often not sufficient to impart solubility and cause adherence of the dye to fiber. The auxochrome or bonding affinity groups are amine, hydroxyl, carboxyl and sulfonic radicals, or their derivatives. These auxochromes are important in the use classification of dyes ${ }^{[45]}$.

Under the low $\mathrm{pH}$ conditions used in our study, neither one of the oil components joined with the dye components. However, the observed reduction in the absorbance can be explained as a result of the splitting of the dye into two components that may have either lost some of their original color or had different colors that could not be effectively measured at the $475 \mathrm{~nm}$ wave length.

Alkaline condition: Under alkaline condition (high $\mathrm{pH})$, the dye loses one hydrogen ion $\left(\mathrm{H}^{+}\right)$from carbon \# $7^{\prime}$ which reacts with a hydroxyl group $\left(\mathrm{OH}^{-}\right)$from the alkaline media to form water $\left(\mathrm{H}_{2} \mathrm{O}\right)$. This results in the transformation of the neutral compound to an ionic form having a negative charge at carbon \# $7^{\prime}$ $\left[\mathrm{C}_{22} \mathrm{H}_{15} \mathrm{~N}_{2} \mathrm{Na}_{2} \mathrm{O}_{11} \mathrm{~S}_{3}\right]$. Electrons are then transferred from the adjacent sulfonyl group to carbon \# $7^{\prime}$ resulting in a structure that has a sulfur carbon double 
Step 1

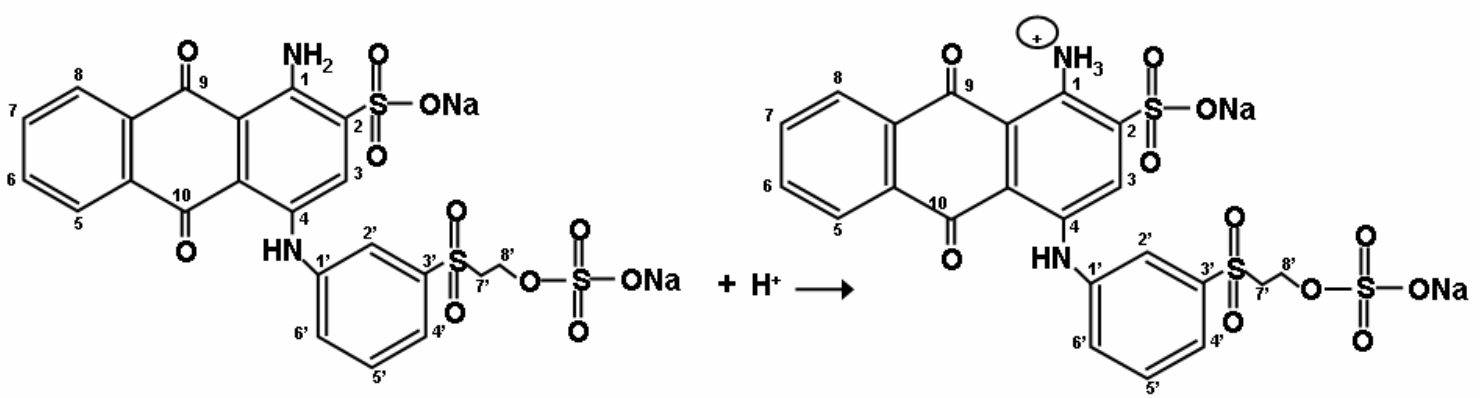

Step 2<smiles>[NH-]c1c(S(=O)(=O)O[Na])cc(Nc2ccc3c(c2)C(=O)c2ccccc2C3=O)c2c1C(=O)c1ccccc1C2=O</smiles>

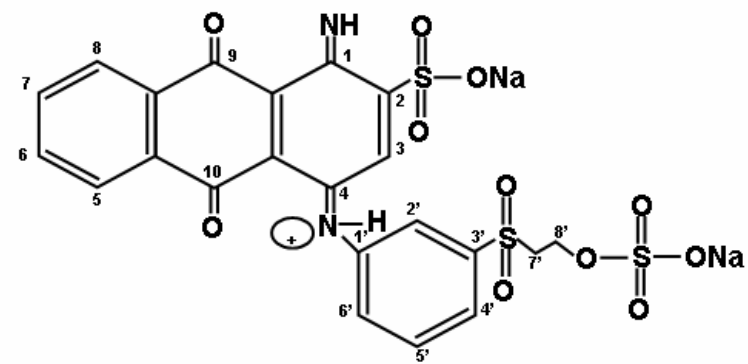

Step 3<smiles>N=c1c2c(=O)c3c([N+](=O)[O-])cc(S(=O)(=O)O[Na])cc3c(=O)c=2c(=O)c2ccccc12</smiles>

Fig. 9: Effect of low $\mathrm{pH}$ on the structure of remazol blue dye $\mathrm{e}^{[19]}$<smiles>O=[N+]([O-])c1ccc(C(OS(=O)(=O)O[Na])OS(=O)(=O)O[Na])cc1</smiles>

bond $(\mathrm{S}=\mathrm{C})$ and a negative charge on the oxygen atom of the sulfonyl group as shown in Fig. $10^{[46]}$.

Although plant oils may hydrolyze slowly in alkali media $^{[43]}$, this reaction does not take place within the time frame of these experiments. The molecules of the oil (which remained neutral) were attached to the ionic form of the dye in the presence of water. When the dye solution was shaken with oil, it formed a colloidal solution containing the oil plus all the dye structure as shown in Fig. 11.

Optimum removal conditions: The optimum conditions for the removal of dye for various oils are shown in Table 6. Most oils produced the highest removal efficiency at a $\mathrm{pH}$ of 13 and a temperature of $55^{\circ} \mathrm{C}$ except canola oil which produced the highest dye 
<smiles>C[C@H](CS(=O)(=O)O[Na])OS(=O)(=O)c1cccc(Nc2cc(S(=O)(=O)O[Na])c(N)c3c2C(=O)c2ccccc2C3=O)c1</smiles>

Step 2<smiles>Nc1cc(S(=O)(=O)[O-])c(Nc2ccc3c(c2)C(=O)c2ccccc2C3=O)cc1S(=O)(=O)O[Na]</smiles><smiles></smiles>

Fig. 10: Effect of high $\mathrm{pH}$ on the structure of remazol blue dye $\mathrm{e}^{[46]}$ 

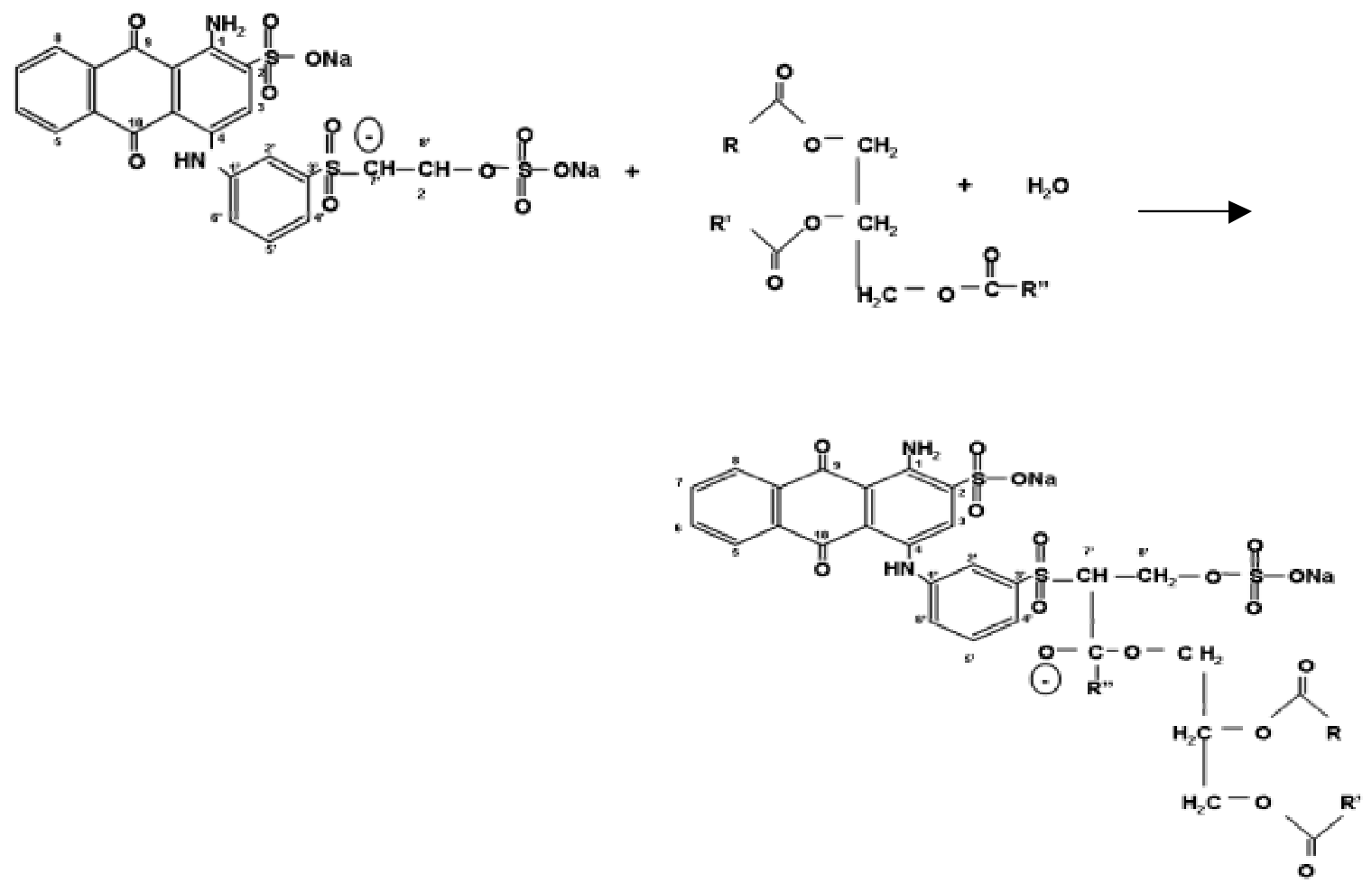

Step 2
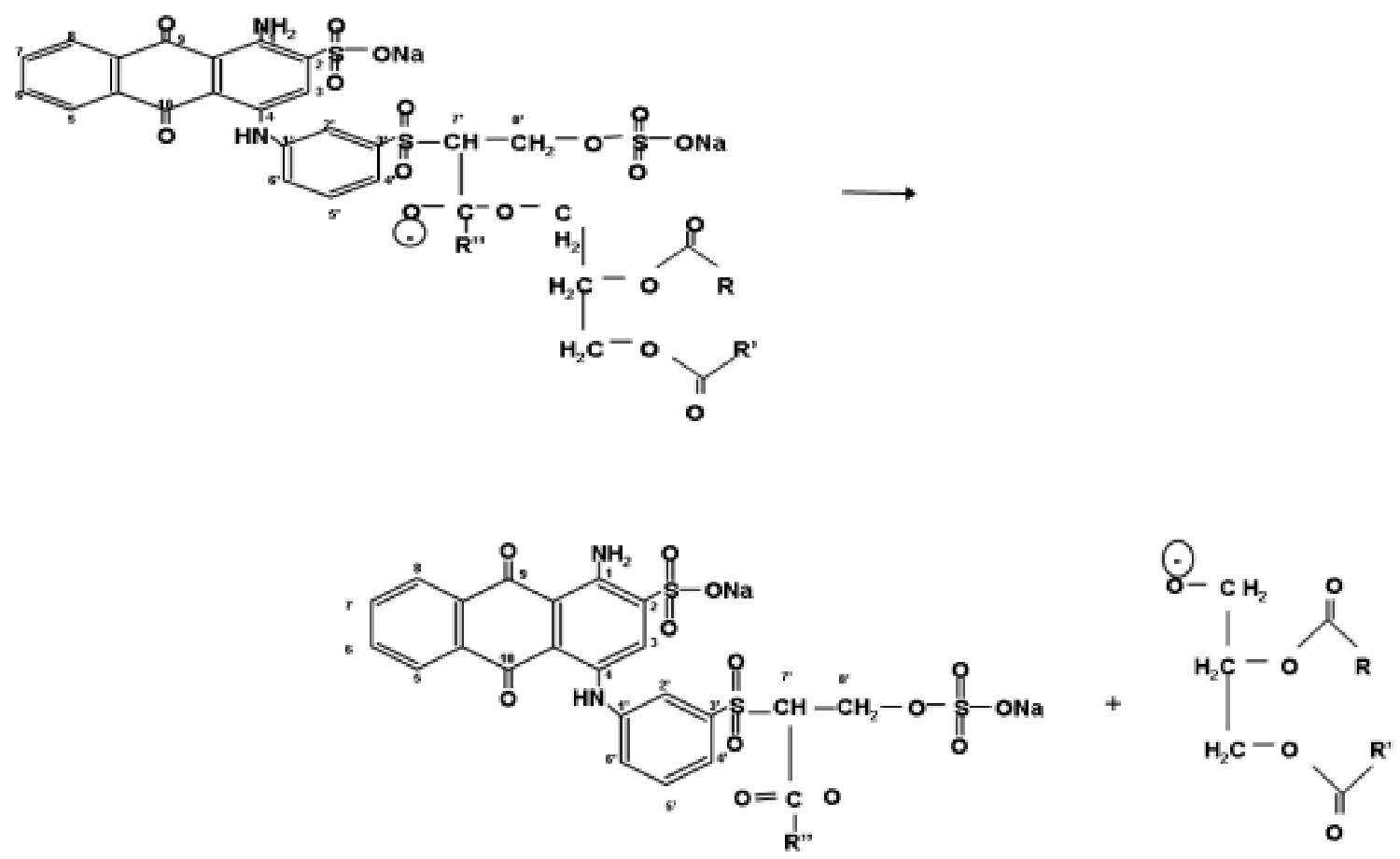

Fig. 11: Proposed mechanism for interaction between remazol dye and plant oil under high $\mathrm{pH}$ condition 
Table 6: Optimum condition for dye reduction (\%) using different

\begin{tabular}{lrcc}
\multicolumn{1}{c}{ oils } & & & \\
\hline Oil & $\mathrm{pH}$ & Temperature $\left({ }^{\circ} \mathrm{C}\right)$ & Reduction $(\%)$ \\
\hline Cottonseed & 13 & 55 & 58.06 \\
Olive & 13 & 55 & 87.00 \\
Canola & 7 & 55 & 53.06 \\
Sunflower & 13 & 55 & 58.08 \\
Used cooking oil & 13 & 55 & 95.45 \\
\hline
\end{tabular}

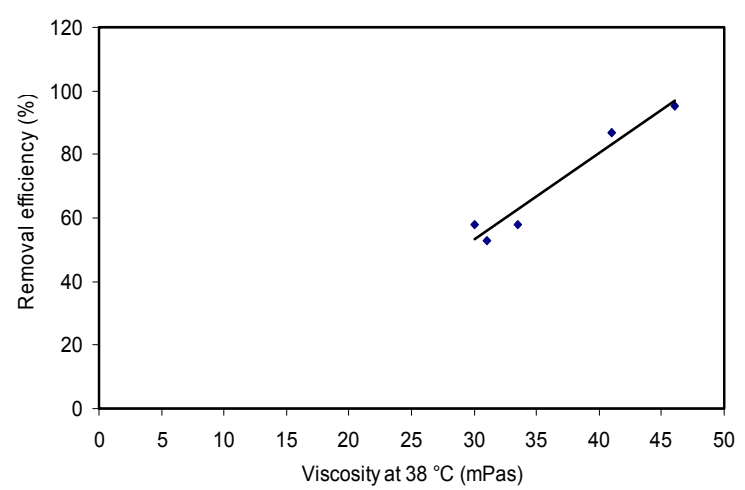

Fig. 12: Relationship between oil viscosity and dye removal efficiency

removal efficiency at a $\mathrm{pH}$ of 7 . The results also showed that the used cooking oil achieved the highest dye removal efficiency $(95.45 \%)$ followed by olive oil $(87.00 \%)$. The other oils (cottonseed, canola and sunflower achieved dye removal efficiencies below $58 \%$ and are, therefore, not recommended for dye removal. The removal efficiency was correlated to the viscosity of the oil (Table 2) as shown in Fig. 12. Viscosity has been used to assess chemical charges and characterize fluid textures. In vegetable oils ${ }^{[47]}$, viscosity increases with the chain length of triglyceride fatty acids and decreases with the unstauration. It is a function of molecules' dimension and orientation ${ }^{[48]}$. Santose et $a l^{[35]}$ reported that after exposing oil to temperature typically used in frying, the viscosity of the oil increases with frying time. This has been attributed to oxidation and polymerization reactions and the thermal degradation of the oil

\section{CONCLUSION}

Dye removal from textile wastewater was achieved using plant oils (cottonseed, olive, canola sunflower and used cokking oil). The study revealed that the dye removal efficiency increased as the temperature of the medium increased. Under low $\mathrm{pH}$, both the oil and dye split into two components each. The dye split into: one compound carrying a positive charge at $\mathrm{NH}_{3}$ which is located at carbon \# 1' on the benzyl ring as chromogen and the other compound containing the anthraquinone rings which is considered to be the chromophore in the dye structure. The oil split into: diglyceride, free fatty acid and hydrogen ion. Neither one of the oil components joined with either one of the dye components. The observed reduction in the absorbance under acidic conditions can be explained as a result of the dye components either losing some of their original color or producing different colors that could not be effectively measured at the $475 \mathrm{~nm}$ wave length. When the dye solution was shaken with the oil under alkaline conditions, it formed a colloidal solution containing the oil plus the dye, thereby resulting in a significant dye removal from the solution. The results also showed that the optimum conditions for the dye removal for various oils were a pH of 13 and a temperature of $55^{\circ} \mathrm{C}$, except for canola oil that produced the highest dye removal efficiency at $\mathrm{pH}$ of 7 . The used cooking oil achieved the highest dye removal efficiency $(95.45 \%)$ followed by olive oil $(87.00 \%)$. The other oils (cottonseed, canola and sunflower achieved dye removal efficiencies below $58 \%$ and are, therefore, not recommended for dye removal.

\section{ACKNOWLEDGMENTS}

The National Science and Engineering Research Council (NSERC) of Canada financially supported this study. The postdoctoral fellowship provided by the Egyptian Ministry of Higher Education is highly appreciated.

\section{REFERENCES}

1. Sarina, J.E.M., M.T. Brian and A.R.M. Reckhow, 2006. Evaluation of water treuse technologies for the textile industry. J. Environ. Eng., 3: 315-322.

2. Yang, X.Y. and B. Al-Duri, 2001.Application of branched pore diffusion model in the adsorption of reactive dyes on activated carbon. Chem. Eng. J., 83: 15-23.

3. O'Mahony, T., E. Guibal and J.M. Tobin, 2002. Reactive dye biosorption by Rhizopus arrhizus biomass. Enzyme Microb. Technol., 31: 456-463.

4. Raymound, E.K. and F. Dunald, 1984. Encyclopedia of Chemical Technology. John Wiley, New York, USA.

5. Papic, S., N. Koprivanac, A.L. Bozic and A. Metes, 2004. Removal of some reactive dyes from synthetic wastewater by combined $\mathrm{Al}(\mathrm{III})$ coagulation/carbon adsorption process. Dyes Pigments, 62: 291-298. 
6. Lee, J. W., S.P. Choi, R. Thiruvenkatachari, W.G. Shim and H. Moon, 2006. Evaluation of performance of adsorption and coagulation processes for the maximum removal of reactive dyes. Dyes and Pigments, 69: 196-203.

7. Sponza, D.T. and M. Isik, 2005. Toxicity and intermediates of C.I. direct red 28 dye through sequential anaerobic/aerobic treatment. Process Biochem., 40: 2735-2744.

8. Pandit, P. and S. Basu, 2002. Removal of organic dyes from water by liquide liquid extraction using reverse micelles. J. Colloid Interface Sci., 24: 208214

9. Mittal, A., L. Kurup and V.K. Gupta, 2005. Use of waste materials-bottom ash de-oiled Soya, as potential adsorbents for the removal of Amaranth from aqueous solution. J. Hazard. Mater., 117: 171-178.

10. Sanghi, R, B. Bhattacharya and W. Qual, 2002. Can. J. Forest Res., 38: 553.

11. Van der Bruggen, B., I. De Vreese and C. Vandecasteele, 2001. Water reclamation in the textile industry: Nanofiltration of dye baths for wool dyeing. Indust. Eng. Chem. Res., 40: 39733978.

12. Koyuncu, I., 2003. Direct filtration of procion dye bath wastewaters by nanofiltration membranes: Flux and removal characteristics. J. Chem. Technol. Biotechnol., 78: 1219.

13. Roy, D., K.T. Valsaraj and S.A. Kottai, 1992. Separation of organic dyes from wastewater by using colloidal gas aphrons. Separation Sci. Technol., 27: 573-88.

14. Ge, J. and J. Qu, 2003. Degradation of azo dye acid red $\mathrm{B}$ on manganese dioxide in the absence and presence of ultrasonic irradiation. J. Hazard. Mater., 100: 197-207.

15. Alinsafi, A., M. Khemis, M.N. Pons, J.P. Leclerc, A. Yaacoubi, A. Benhammou and A. Nejmeddine, 2004. Electro-coagulation of reactive textile dyes and textile wastewater. Chem. Eng. Process., 44: 461-470.

16. Liu, R.L.H., H.-M. Chiu and R.Y.L. Yeh, 2003. Colloid interaction and coagulation of dye wastewater with extra application of magnetites. Intl. J. Environ. Studies, 59: 143-158.

17. Arslan, I., I.A. Balcioglu and T. Tuhkanen, 2000. Treatability of simulated reactive dye-bath wastewater by photochemical and nonphotochemical advanced oxidation processes. J. Environ. Sci. Health, 35: 775-793.
18. López-Grimau, V. and M.C. Gutiérrez, 2006. Decolorisation of simulated reactive dye bath effluents by electrochemical oxidation assisted by UV light. Chemosphere, 62: 106-112.

19. Patricia, A.C., E.O. Marly, E. Osugi, C.S. Fugivara, N. Boralle, M. Furlan and M. Zanoni, 2005. Evalution of different electrochemical methods on the oxidation and degradation of reactive blue 4 in aqueous solution. Chemosphere, 59: 431-439.

20. Lee, D. W., R. Won and H. K. Yup, 2000. Removal of an organic dye from water using a predispersed solvent extraction. Separation Sci. Technol., 35: 1951-1962.

21. Snider, E.H. and J.J. Porter, 1994. Ozone treatment of textile wastes. Journal of the Water Pollution Control Federation, 46: 886.

22. Beszedits, S., 1980. Ozonation to decolor textile effluents. American Dyestuffs Report, 69:38.

23. Green, J.M. and C. Sokol, 1985. Using ozone to decolorize dyeing plant wastewater. American Dyestuff Report, 74: 67.

24. Gould, J.P. and K.A. Groff, 1987. Kinetics of ozonolysis of synthetic dyes. Ozone Sci. Eng., 9: 153.

25. Murphy, J., G. Joseph, L. Long, K. Mitchell and G.V. Poje, 2001. Hazard Investigation of Reactive Chemicals. Process Safety Progress, 20: 253-256.

26. Venkateswaran, P. and K. Palanivelu, 2006. Recovery of phenol from aqueous solution by supported liquid membrane using vegetable oils as liquid membrane. J. Hazard. Mater., 131: 146-152.

27. Kasuga, K.T. S. Hirose, T. Aiba, S. Takahashi and K. Hiratani, 1998. Transport of monosaccharide through a liquid membrane mediated by lipophilic alkalic earth metal complex. Tetrahedron Lett., 39: 699-702.

28. Beydilli, M.I., S.G. Pavlostathis and W.C. Tincher, 2000. Biological decolorization of the azo dye reactive red 2 under various oxidation-reduction conditions. Water Environ. Res., 72: 698-705.

29. Liakou , S., U. Zissi, M. Kornaros and G. Lyberatos, 2003. Combined chemical and biological treatment of azo dye-containing wastewaters. Chem. Eng. Commun., 190: 645-661.

30. Ehud, N.L., S.P. David, A.M. Asce, J.E. Sarina, P.E. Ergas, A.M. Asce, R.A. David and A.M. Asce, 2006. Electrochemical oxidation and ozonation for textile wastewater reuse. J. Environ. Eng., 3: 324330. 
31. Robinson, T., G. Mc Mullan, R. Marchant and P. Nigam, 2001. Remediation of dyes in textile effluent a critical review on current technologies with a proposed alternative. Bioresource Technol., 77: 247-255.

32. Crini, G., 2006. Non-conventional low-cost adsorbents for dye removal: A review. Bioresource Technol., 97: 1061-1085.

33. Abramovic, H. and C. Klofutar, 1998. The temperature dependence of dynamic viscosity for some vegetable oils. Acta Chimica Slovenica, 45: 69-77.

34. Fountain, C.W., J. Jennings, M.K. Cheryl, O. Patrice and M.L. Fetterol, 1997. Viscosity of common seed and vegetable oils. J. Chem. Edu., 74: 224-227.

35. Santos, J.C.O., I.M.G. Santos and A.G. Souza, 2005. Effect of heating and cooling on rheological parameters of edible vegetable oils. J. Food Eng., 67: 401-405.

36. Mahmoud A.S., A.E. Ghaly and S.L. Brooks, 2007. Influence of temperature and $\mathrm{pH}$ on the stability and colorimetric measurement of textile dyes. Am. J. Biotechnol. Biochem., 3: 33-41.

37. Mittal, A., L. Krishnan and V.K. Gupta, 2005. Removal and recovery of malachite green from wastewater using an agricultural waste material, de-oiled soya. Separation and Purification Technol., 43: 125-133.

38. Muthuraman, G. and K. Palanivelu, 2006. Transport of textile dye in vegetable oils based supported liquid membrane. Dyes and Pigments, 70: 99-104.

39. Al-Qodah, S.U., M. Zissi, G. Kornaros and S. Lyberatos, 2003. Vegetable oil is an alternative fuel for diesel engine. Chem. Eng. Commun., 190: 645 .
40. Tsatsaroni, E.G., 1996. Structure-stability Relationships in some Azo Disperse Dyes. Dyes and Pigments, 31: 301-307.

41. Bohacova, V., P. Docolomansky, A. Breier, P. Gemeiner and A. Ziegelhoffer, 1998. Interaction of lactate dehydrogenase with anthraquinone dyes:characterization of ligands for dye-ligand chromatography. J. Chromatography, 715: 273281.

42. Clair, N.S., L.M. Perry and F.G. Parkin, 1994.Chemistry for Environmental Engineering, McGraw-Hill Inc., New York.

43. Carmen, S., M. Vinatoru and Y. Maeda, 2006. Ultrasonic versus silent methylation of vegetable oils. Ultrasonics Sonochemistry, 13: 401-407.

44. Benelield, L., W.E. Hill, W.C. Tincher and F. Cook, 1993. Source reduction of pollutants from textile processing waste water. National Textile Center Quarterly and Report, 26-28, WinstenSalem,North Carolina.

45. Cooper, P., 1992. Overview of the effect of environmental legislation on the UK textile wet processing industry. J. Society Dyers Colorist, 108: 176-82.

46. Nagendrappa, G., 2004 . An epitome of K venkataraman's chemistry. Resonance, 12: 45-51.

47. Rao, M.A., 1997. Rheology of liquid foods: A review. J. Texture Studies, 8: 135-168.

48. Santos, J.C., I.M.G. Santos, M.M. Goncecao, S.L. Porto, M.F.S. Trindaste, A.G. Souza, S. Prasad and V.J. Fernandes, 2004. Thermoanalytical, kinetic and rheological parameters of commercial edible vegetable oils. J. Thermal Analysis and Colorimetry, 72: 419-428. 